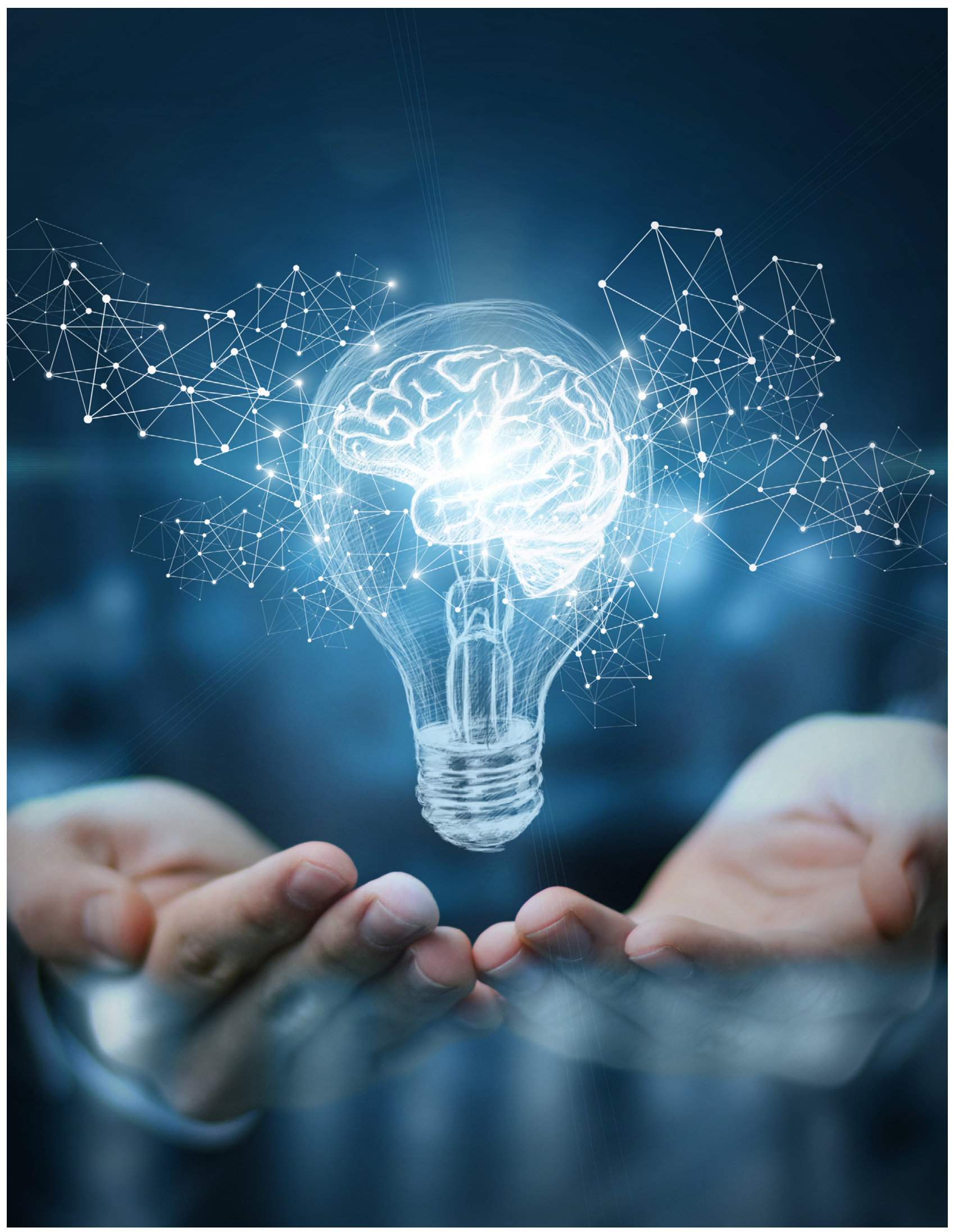




\section{EDUCAÇÃO PARA UM DESENVOLVIMENTO SUSTENTÁVEL}

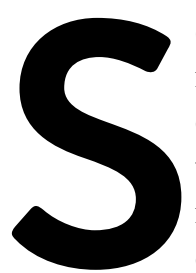

e a economia brasileira voltar a prosperar, vamos enfrentar o mesmo problema do último ciclo de crescimento de alguns anos atrás: falta de talentos e de pessoas capacitadas para as mais diversas posições nas empresas. E não há dúvida de que a educação é um fator essencial para uma qualificação profissional de excelência e para um círculo virtuoso de desenvolvimento econômico e social.

Esta edição da $G V$-executivo está especialmente rica ao debater esse tema por diferentes perspectivas. No Caderno Especial, apresentamos um conjunto de artigos que enfatizam a importância da internacionalização das escolas de negócios não só para o aprimoramento pessoal, mas também para as empresas e para a sociedade.

Com uma visão abrangente do cenário internacional, o artigo de Julia von Maltzan Pacheco, Escolas em rede, elenca os benefícios das diversas redes internacionais de escolas de negócios que promovem atividades de intercâmbio entre estudantes, professores e pesquisadores, com o objetivo de preparar os alunos para o mercado global. Em Diferencial competitivo, Marcello Romani-Dias e Jorge Carneiro tratam de programas de Master in Business Administration (MBA) que inserem experiências internacionais para seus alunos, mostrando que tais vivências constituem ativos essenciais para a carreira. Mas não só na educação executiva essa questão se faz essencial. $\mathrm{O}$ artigo Trilhas que se abrem, de Renato Guimarães Ferreira, Felipe Zambaldi e Gisele Walczak Galilea, mostra a experiência bem-sucedida da internacionalização do curso de graduação em Administração de Empresas da FGV EAESP.

O Caderno conta também com a colaboração internacional de escolas parceiras da FGV EAESP: Lu Xiongwen, da chinesa Universidade de Fudan, no artigo Estratégia de alcance global, revela como essa escola de negócios construiu uma estratégia em linha com o desenvolvimento econômico da China para ganhar destaque mundialmente; e Stefano Caselli, da italiana Universidade Luigi Bocconi, no artigo Tudo vai mudar, aponta para as profundas transformações por que passam as escolas de negócios para enfrentar, ao mesmo tempo, os desafios globais e as especificidades locais.

No escopo do Especial, destaca-se ainda a entrevista com Santiago Iñiguez de Onzoño, presidente executivo da IE University, em Madri. Em recente passagem pelo Brasil, Santiago concedeu uma entrevista exclusiva à GV-executivo, em que aborda as transformações, os desafios e as tendências do ensino nas universidades, enfatizando a importância das ciências humanas para a formação de profissionais capazes de interagir melhor com seus pares e ganharem flexibilidade em um mercado de trabalho que muda rapidamente.

Para completar as enriquecedoras perspectivas que esta edição traz na área da educação, Fernando Luiz Abrucio, no artigo Separar o joio do trigo: o que importa na educação, apresenta a história (e as dificuldades) da educação no Brasil e expõe propostas concretas de melhoria.

Os dois últimos artigos exploram temas relevantes na atualidade: em (In)Decisões financeiras para a aposentadoria, Claudia Emiko Yoshinaga trata de questões comportamentais que fazem com que os brasileiros poupem menos do que deveriam, um tema mais do que atual diante da possível reforma da previdência; e em Negócios como destino, Wandick Leão e Juliana Bonomi Santos falam da complexidade da experiência de serviços hoje em dia.

Para fechar a edição, temos as colunas de Benjamin Rosenthal, sobre o lado político das marcas; de Amon Narciso de Barros, a respeito dos novos arranjos políticos no Brasil; além das tradicionais colaborações de Samy Dana neste número sobre dinheiro x presente - e Paulo Sandroni - a respeito da tempestade no setor externo e das incertezas no plano interno -, com debates atuais e provocadores.

Maria José Tonelli - Editora chefe

Adriana Wilner - Editora adjunta 